\section{Institute of Metals Medals}

THE Council of the Institute of Metals has made the following awards of medals: The Institute of Metals (Platinum) Medal to Dr. L. B. Pfeil (director, Mond Nickel Co., Ltd.) in recognition of his outstanding contributions to non-ferrous metallurgical science and to the non-ferrous metals industries; The Rosenhain Medal to Prof. R. W. K. Honeycombe (professor of physical metallurgy, University of Sheffield) in recognition of his outstanding contributions in the field of physical metallurgy; The W. H. A. Robertson Medal and Premium to Dr. R. B. Sims (chief engineer, Davy and United Engineering Co., Ltd.) for a paper on "Automatic Gauge Control in Rolling Mills", published in the Journal of the Institute of Metals, 86 (1957-58).

\section{World Life Research Institute}

Bruce W. Halstead, formerly of the School of Tropical and Preventive Medicine, College of Medical Evangolists, Loma Linda, California, has recently been appointed director of the World Life Research Institute now under construction in Reche Canyon, Colton, California. The new institute will be operated as a non-profit-making, scientific and educational organization with emphasis on fundamental research in the broad field of the chemistry of natural products ; for example, phytochemistry and marine biotoxicology. The application of these compounds to medicine and industry is also of direct interest to the organization. Research will be conducted under contract and grants-in-aid from government and industry. A technical assistance programme will be developed, working in conjunction with certain under-developed countries, in the chemistry of natural products.

\section{Colonial Development and Welfare}

IN moving the second reading of the Colonial Development and Welfare Bill in the House of Commons on March 2, the Secretary of State for the Colonies, Mr. A. Lennox-Boyd, said that the background to the Bill was explained in the report on the use of funds provided under the Colonial Development and Welfare Acts and outline of the proposal for exchequer loans to the Colonial territories issued as a White Paper (Cmnd. 672). The first part of the Bill extends the period of the existing Colonial Development and Welfare Acts and increases the money available for schemes made under the Act. All but 2 per cent of the money provided under the Acts had been in the form of grants, and expenditure was now running at over £12 million a year ; from April 1946 to March 1958 it totalled $£ 155,418,000$. Of this, $£ 13,255,000$ was for research, for which cornmitments in the period totalled $£ 17,203,000$ or 8.9 per cent of the total, while a further $21 \cdot 2$ per cent was for communications, 14.2 per cent for agriculture, fisheries and forestry, 4.4 per cent for irrigation and soil conservation and 18.3 per cent for education. The latter figuro included grants of $£ 1,244,250$ to the University College of Rhodesia and Nyasaland and $\mathfrak{1 , 5 0 0 , 0 0 0}$ to the University of Malaya. Although some of the territories had now become self-governing Dominions, which under Clause $2(7)$ of the Bill would cease to be eligible for Colonial Development and Welfare assistance, over the whole field more than four times as many administrative, technical and professional officers are being recruited than before the War. Mr. Lennox-Boyd referred particularly to the value of the work of the technical advisers to the Federal Government of the West Indies.
The Bill would provide $£ 95$ million of new money over the next five years, compared with $£ 80$ million made available in 1955 on the present quinquennium. Excluding the $£ 24$ million to be allocated to Malta but including the $\mathbf{f 4 4}$ million unexpended under the previous Acts, this would give $£ 115$ million for spending in the five years from April 1, 1959. In several territories the immediate effect of development has been to increase the demand on Government resources, and as external financial aid, mainly from the United Kingdom, is likely to be needed for many years the Bill introduced a novel plan of Exchequer loans. Provision was made for up to $£ 100$ million of such loans from the Government fund, over five years normally, to meet the cost of the loan-worthy element to general development programmes. 'The terms of these Exchequer loans will be fixed by the Secretary of State for the Colonies with the approval of the Treasury, but will not be more favourable than those on market issues. Mr. Lennox-Boyd said that the Bill was the next step in a programme of continuous assistance to Colonial governments and believed that it could facilitate a substantial expansion in development.

\section{Funds for Commonwealth Students in Britain}

IN a statement circulated in Hansard for March 9, the Under-Secretary of State for Commonwealth Relations, Mr. C. J. M. Alport, said that of the $£ 620,500$ from United Kingdom Government funds available to Commonwealth and Colonial students in 1958-59 for study in the United Kingdom, $£ 180,000$ is under Colonial Development and Welfare, $£ 315,000$ under the Colombo Plan Technical Co-operation Scheme, $£ 66,400$ for British Council scholarships and bursaries, $£ 4,500$ under technical assistance to Ghana, $£ 600$ for the Federation of Malaya Merdeke Scholarship, $£ 4,000$ under Baghdad Pact technical assistance and $£ 50,000$ for Athlone fellowships. These funds are not necessarily restricted to university students but are available for further education or training at any suitable centre in Great Britain. In addition, a wide range of scholarships tenable in Britain is offered by the United Nations Special Agencies, charitable and educational trusts, universities, business firms and others.

\section{Nato Studentships and Fellowships}

Is a written answer in the House of Commons on March 2, the Parliamentary Secretary to the Ministry of Works, Mr. H. Nicholls, representing the Lord President of the Council, said that the North Atlantic Council had decided to finance a science studentship and fellowship programme to start this year. The Department of Scientific and Industrial Research, in consultation with other interested Government bodies, would make these awards to British subjects normally resident in Britain. Under the programme the United Kingdom proposed to provide increased opportunity for study, research training and experience for postgraduate and postdoctoral students in science and technology (including modical and agricultural sciences, industrial psychology and sociology). The scheme was intended to stimulate international exchange of such students between North Atlantic Treaty Organization countries, but awards could be held in the home country of a student or in a country which was not a member of the Organization. The value of the awards and their conditions would be generally similar to those for studentships and fellowships of the Department of Scientific and Industrial Research. 